\title{
Identifikasi Kadar Semen dan Pasir Melalui Citra Permukaan Menggunakan Teknik Blok Citra
}

\author{
Gasim* $^{* 1}$, Sudiadi ${ }^{2}$, Desy Iba Ricoida ${ }^{3}$, Rusbandi $^{4}$, Rizani Teguh $^{5}$ \\ ${ }^{1,4}$ Program Studi Teknik Informatika, STMIK Global Informatika MDP \\ ${ }^{2,3,5}$ Program Studi Sistem Informasi, STMIK Global Informatika MDP \\ e-mail: ${ }^{1 *}$ gasim@mdp.ac.id, ${ }^{2}$ sudiadi@mdp.ac.id, ${ }^{3}$ desih@mdp.ac.id, \\ ${ }^{4}$ rusbandi@mdp.ac.id, ${ }^{5}$ rizani_teguh@mdp.ac.id
}

\begin{abstract}
Abstrak
Penelitian ini mengangkat topik identifikasi jenis campuran semen dan pasir pada material yang sudah kering menggunakan kecerdasan buatan. Hal ini dilakukan karena perbandingan campuran antara semen dan pasir sangat berpengaruh pada kualitas material yang dihasilkan. Beberapa model eksperimen berpengaruh terhadap tingkat akurasi pengenalan. Pada penelitian ini model eksperimen yang digunakan adalah teknik blok citra dan citra LBP, dengan jenis campuran semen dan pasir yang digunakan adalah 1:1 , 1:1.5 , 1:2 , 1:2.5 , 1:3, dan 1:3.5. Metode pengenalan yang digunakan adalah Jaringan Syaraf Tiruan (JST) dengan algoritma propagasi balik. Banyaknya sampel pelatihan JST adalah 600 sampel, dan 120 sampel untuk pengujian. Penelitian ini menggunakan teknik blok citra sebelum ekstraksi fitur dilakukan. Fitur yang digunakan adalah mean, standar deviasi, entropy, skewness, dan kurtosis dari citra LBP. Hasil pelatihan JST mendapatkan arsitektur tiga lapisan tersembunyi, dengan pengujian menunjukkan tingkat akurasi pengenalan sebesar $80 \%$.
\end{abstract}

Kata kunci-Campuran semen pasir, Teknik blok citra, JST, LBP

\begin{abstract}
Abstrack
This research raises the topic of identifying the types of cement and sand mixtures on dry material using artificial intelligence. This is done because the comparison of the mixture between cement and sand is very influential on the quality of the material produced. Several experimental models affect the level of recognition accuracy. In this study the experimental model used was the image block and LBP image techniques, with a mixture of cement and sand used was 1: 1, 1: 1.5, 1:2, 1:2.5, 1: 3, and 1: 3.5. The recognition method used is Artificial Neural Network (ANN) with back propagation algorithm. The number of ANN training samples is 600 samples, and 120 samples for testing. This research uses image block technique before feature extraction is carried out. The features used are the mean, standard deviation, entropy, skewness, and kurtosis of LBP images. ANN training results get a three-layer hidden architecture, with testing showing an accuracy rate of $80 \%$ recognition.
\end{abstract}

Keywords — cement sand mix, Image block technique, ANN, LBP

\section{PENDAHULUAN}

$\mathrm{S}$ etiap pembentukan objek yang melibatkan unsur campuran semen dan pasir semestinya membutuhkan komposisi campuran yang baik untuk tiap bagiannya. Beberapa jenis campuran yang biasa digunakan antara lain campuran semen dan pasir untuk pemasangan bata, campuran semen dan pasir untuk plesteran dinding, campuran semen, pasir dan batu split untuk beton [1]. Untuk mengetahui kadar campuran semen dan pasir pada campuran yang sudah 
mengeras, misalnya campuran semen dan pasir pada pemasangan bata ataupun plesteran dinding merupakan hal yang sulit.

Dalam disiplin ilmu komputer, salah satu metode yang sering digunakan untuk identifikasi atau pengenalan objek adalah Jaringan Syaraf Tiruan (JST). JST membutuhkan nilai-nilai input yang merupakan ciri dari obek yang akan dikenali. Nilai-nilai ini biasanya didapatkan dari sifat statistik dari citra digital. Diantara nilai-nilai yang biasanya digunakan adalah GLCM, LBP, dan lain-lain.

Penelitian terdahulu identifikasi jenis campuran semen dan pasir melalui citra digital tekstur permukaan campuran semen pasir menggunakan kecerdasan buatan (Jaringan Syaraf Tiruan) dengan ekstraksi ciri dari matrik GLCM. Penelitian tersebut mampu memberikan tingkat akurasi pengenalan $87,33 \%$ [2].

Metode pengenalan JST dengan input tekstur analisis sering digunakan pada penelitian identifikasi objek. Diantara penelitian yang menggunakan JST dan tekstur analisis yang menjadi referensi dalam penelitian ini adalah diagnosis dini kanker kulit (melanoma) dengan cara klasifikasi gambar dermoscopy berdasarkan nilai GLCM menggunakan metode Multilayer perceptron classifier (MLP) untuk mengklasifikasikan antara Melanocytic Nevi dan Melanoma maligna, penelitian ini memberikan tingkat akurasi 92\% [3].

Identifikasi cacat pada tekstur menggunakan metode pengenalan JST dan fitur GLCM sebagai input, menghasilkan tingkat akurasi keberhasilan identifikasi $91 \%$ s.d. $100 \%$ [4]. Pengenalan tekstur (texture recognition) menggunakan Artificial Neural Network dengan nilai tekstur sebagai input, menghasilkan tingkat akurasi pengenalan 99.3\% [5]. Pengenalan tekstur kulit menggunakan metode pengenalan Neural Network dengan nilai input berasal dari GLCM, menghasilkan tingkat akurasi pengenalan 96\% [6]. Identifikasi jenis kayu yang menggunakan metode pengenalan JST dan nilai tekstur analisis sebagai input, menghasilkan tingkat akurasi pengenalan $95 \%$ [7].

Penelitian identifikasi kadar semen dan pasir pada campuran semen pasir yang sudah kering belum banyak dilakukan. Tingkat akurasi pengenalan dapat dipengaruhi banyak faktor. Salah satu faktor yang dapat mempengaruhi tingkat akurasi pengenalan adalah metode pengolahan citra digital permukaan sebelum dilakukan ekstraksi fitur. Penelitian ini melakukan pembagian citra menjadi empat bagian (teknik blok citra), sehingga sebuah citra sampel akan memiliki lima citra, sehingga akan terbentuk 20 nilai dari lima fitur yang digunakan.

\section{METODE PENELITIAN}

Secara garis besar urutan penelitian ini disajikan pada Gambar 1. Gambar 1 merupakan urutan kegiatan penelitian ini yang diawali dengan identifikasi masalah serta studi pustaka dan literatur guna mendapatkan informasi terkait objek dan juga metode yang digunakan pada penelitian ini. 


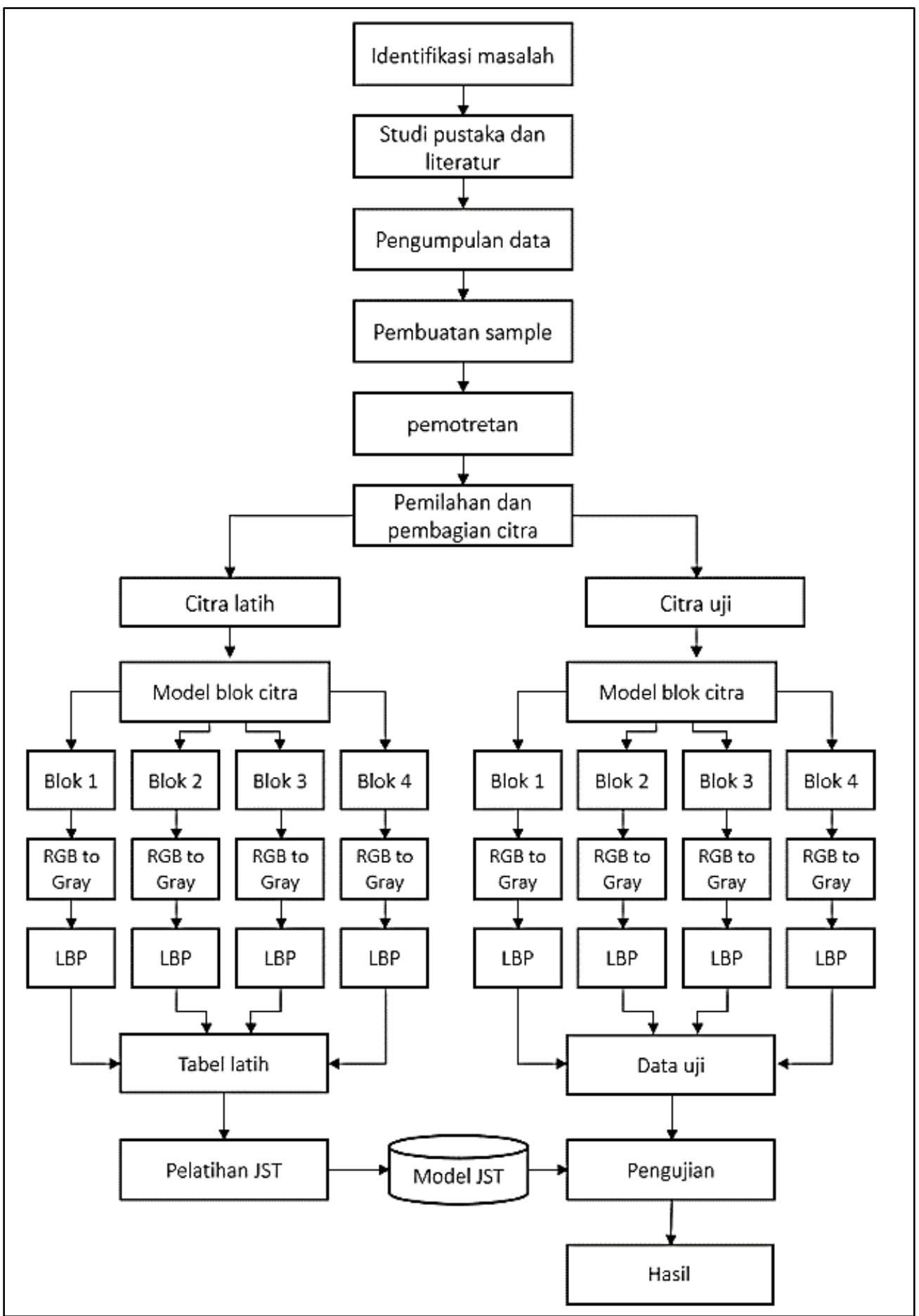

Gambar 1. Metodologi Penelitian

Tahap selanjutnya adalah pengumpulan data yang diawali dengan pembuatan sample, dilanjutkan proses pemotretan, pemilahan citra, dan pemotongan citra. 


\section{Pembuatan Sampel}

Pembuatan sample dilakukan sendiri dengan mencampurkan semen, pasir, dan air ke dalam cetakan. Terdapat enam jenis campuran yang digunakan pada penelitian ini, yaitu 1:1 (1 takar semen dicampur dengan 1 takar pasir), 1:1,5 (1 takar semen dicampur dengan 1,5 takar pasir), 1:2 (1 takar semen dicampur dengan 2 takar pasir), 1:2,5 (1 takar semen dicampur dengan 2,5 takar pasir), 1:3 (1 takar semen dicampur dengan 3 takar pasir), 1:3,5 (1 takar semen dicampur dengan 3,5 takar pasir). Masing-masing campuran tersebut dibuat tiga sample, yaitu dua sampel untuk pelatihan dan satu sampel untuk pengujian. Gambar sampel dapat dilihat pada Gambar 2.

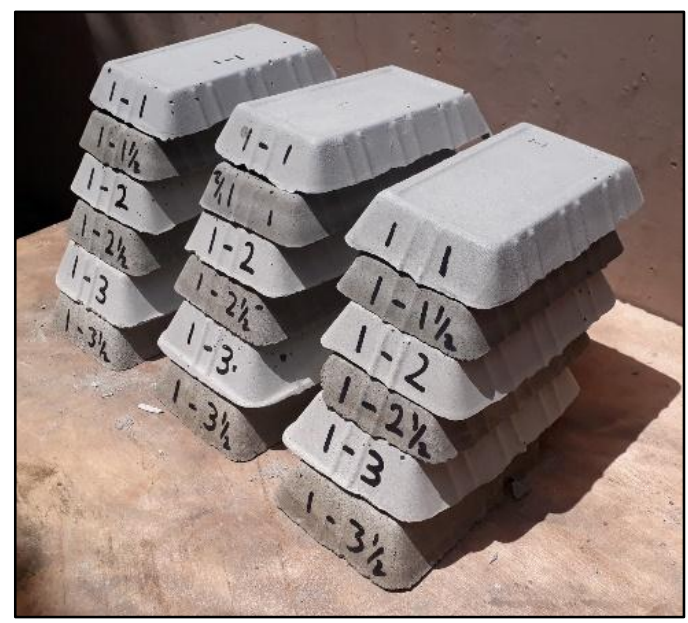

Gambar 2. Sampel objek

\section{Pemotretan}

Pemotretan dilakukan pada bagian permukaan sampel yang sebelumnya sudah di haluskan menggunakan alat yang sama untuk semua sampel. Pemotretan menggunakan kamera biasa Canon PowerShot A2200 HD dengan resolusi pemotretan 7MP (3072 x 2304) dengan posisi kamera lebih kurang tegak lurus (Gambar 3). Pencahayaan saat pemotretan tidak menggunakan pencahayaan kamera, akan tetapi memanfaatkan cahaya matahari disiang hari. Jarak pemotretan untuk semua sampel adalah sama yaitu lebih kurang 8cm (Gambar3).

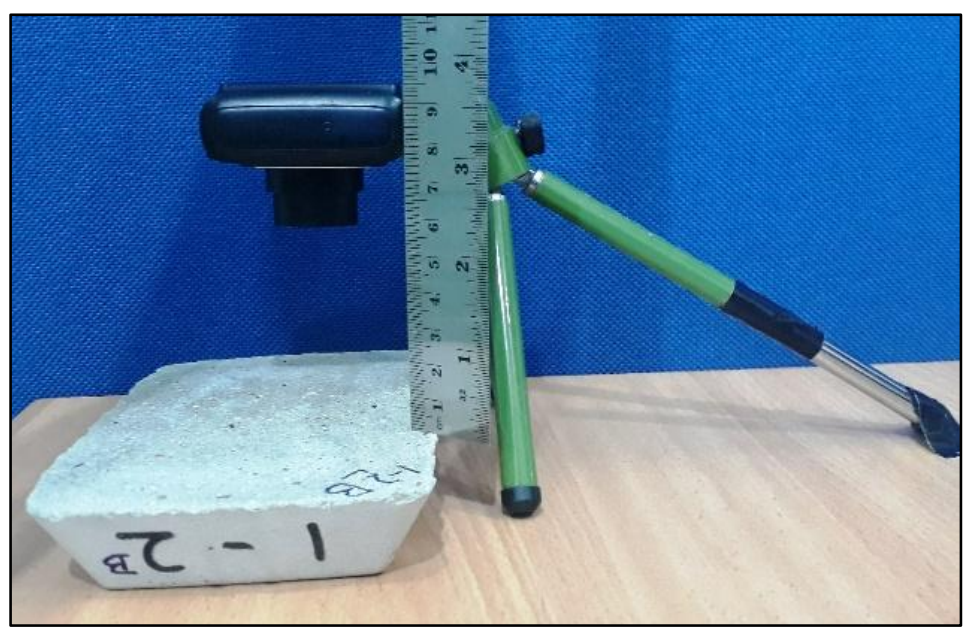

Gambar 3. Pemotretan 


\section{Pemilahan Citra}

Pemilahan citra adalah proses pemisahan antara citra yang fokus dan serta citra yang tidak fokus. Proses ini untuk membuang citra yang tidak fokus dan hanya mengambil citra yang fokus. Contoh citra fokus dan terang serta citra tidak fokus (blur) dapat dilihat pada Gambar 3. Pemilahan ini dilakukan dengan cara mengamati citra secara manual (menggunakan mata) dengan kondisi citra ukuran penuh (100\%). Citra hasil pemilahan terbagi menjadi dua, yaitu citra fokus dan terang, serta citra tidak fokus (blur). Selanjutnya citra hasil pemilahan ini (citra fokus) digunakan pada tahap pelatihan dan pengujian.

\section{Pemotongan Citra}

Citra hasil pemotretan berukuran 1020x 3400 piksel, sedangkan penelitian ini menggunakan citra berukuran 500 x 500 piksel. Pemotongan citra (cropping) merupakan cara mendapatkan citra berukuran $500 \times 500$ piksel. Proses pemotongan citra dapat dilihat pada Gambar 4, yaitu citra hasil pemilahan citra dibuka menggunakan perangkat lunak pengolahan citra, kemudian diamati bagian yang tidak mengandung lubang-lubang dan ditandai dengan ukuran 500 x 500 piksel, selanjutnya dilakukan petongan pada bagian yang sudah ditandai tersebut (Gambar 4).

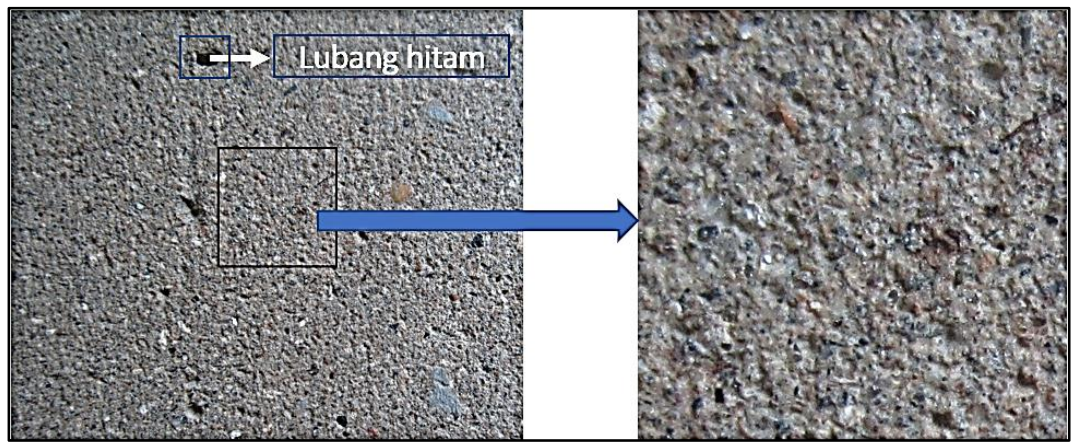

Gambar 4. Ilustrasi Proses Pemotongan Citra

\section{Citra Latih dan Citra Uji}

Setelah dilakukan pemotongan semua citra menjadi 500 x 500 piksel, tahap selanjutnya adalah membagi kumpulan citra tersebut menjadi dua bagian, yaitu citra yang digunakan untuk pelatihan (citra latih), dan citra yang digunakan untuk pengujian (citra uji). Penelitian ini menggunakan 100 citra latih untuk masing-masing jenis campuran, dan 20 citra uji untuk masing-masing jenis campuran (Tabel 1).

Tabel 1. Data Latih dan Uji Tiap Sampel

\begin{tabular}{|l|r|r|r|}
\hline & \multicolumn{2}{|c|}{ Data Latih } & \multicolumn{1}{l|}{ Data Uji } \\
\hline Jenis & Sample 1 & Sample 2 & \multicolumn{1}{l|}{ Sample 3 } \\
\hline $1: 1$ & 50 & 50 & 20 \\
\hline $1: 1,5$ & 50 & 50 & 20 \\
\hline $1: 2$ & 50 & 50 & 20 \\
\hline $1: 2,5$ & 50 & 50 & 20 \\
\hline $1: 3$ & 50 & 50 & 20 \\
\hline $1: 3,5$ & 50 & 50 & 20 \\
\hline total & \multicolumn{3}{|c}{} \\
\hline
\end{tabular}




\section{Ekstraksi Ciri}

Gambar 5 menyajikan tahap ekstraksi ciri (fitur) diawali dengan membagi citra RGB menjadi 4 blok (bagian), kemudian masing-masing bagian dikonversi menjadi citra skala keabuan (Grayscale), dilanjutkan pembentukan matriks LBP, terakhir ekstraksi Mean, standar deviasi, entropy, skewness, dan kurtosis.

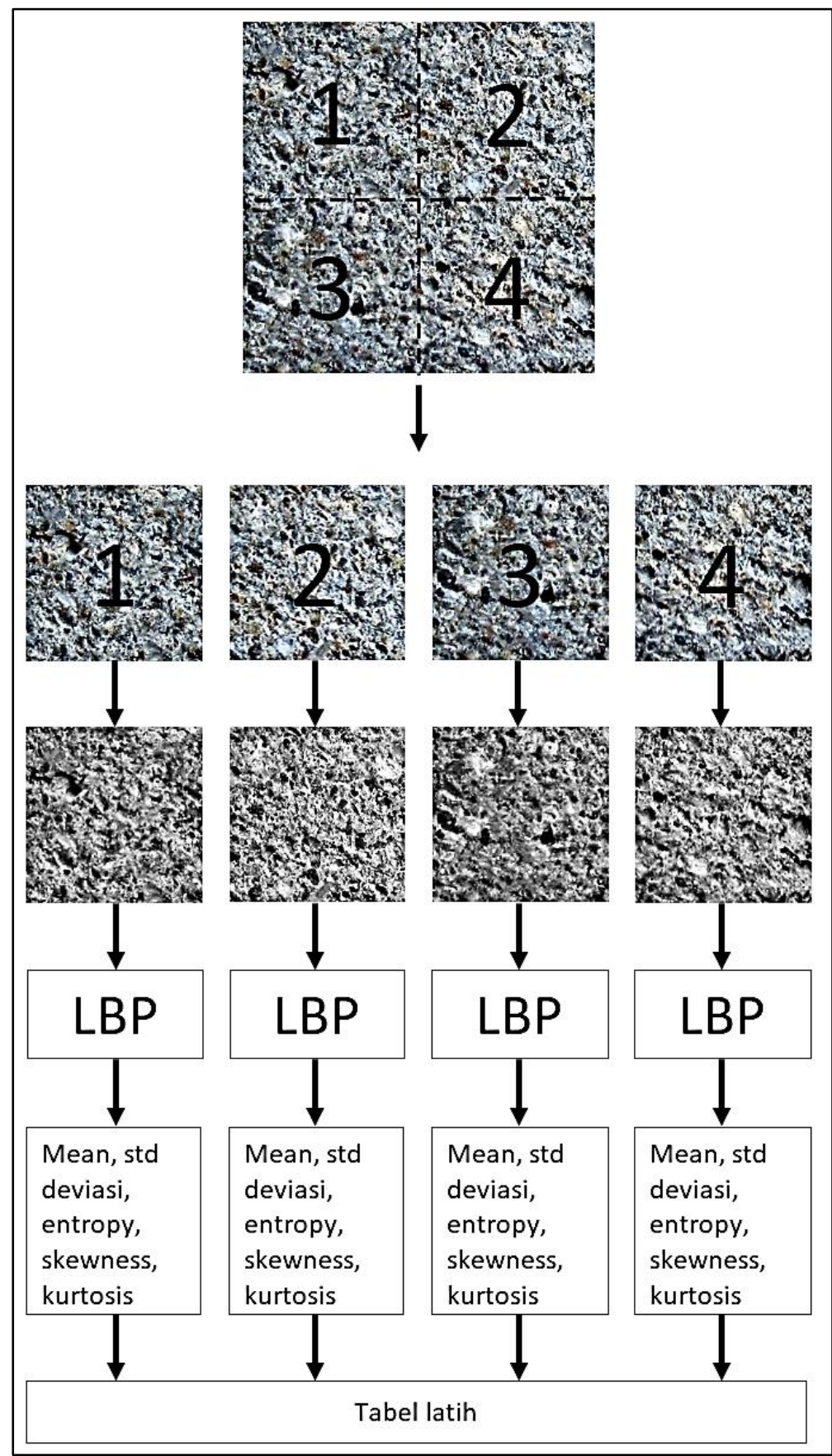

Gambar 5. Tahap Ekstraksi 
Dengan teknik ini maka tiap bagian citra menghasilkan 5 nilai ciri (Fitur), sehingga sebuah citra memiliki 20 nilai ciri (fitur) yang akan digunakan sebagai input pada proses pelatihan JST.

Pembentukan matrik citra LBP menggunakan algoritma berikut:

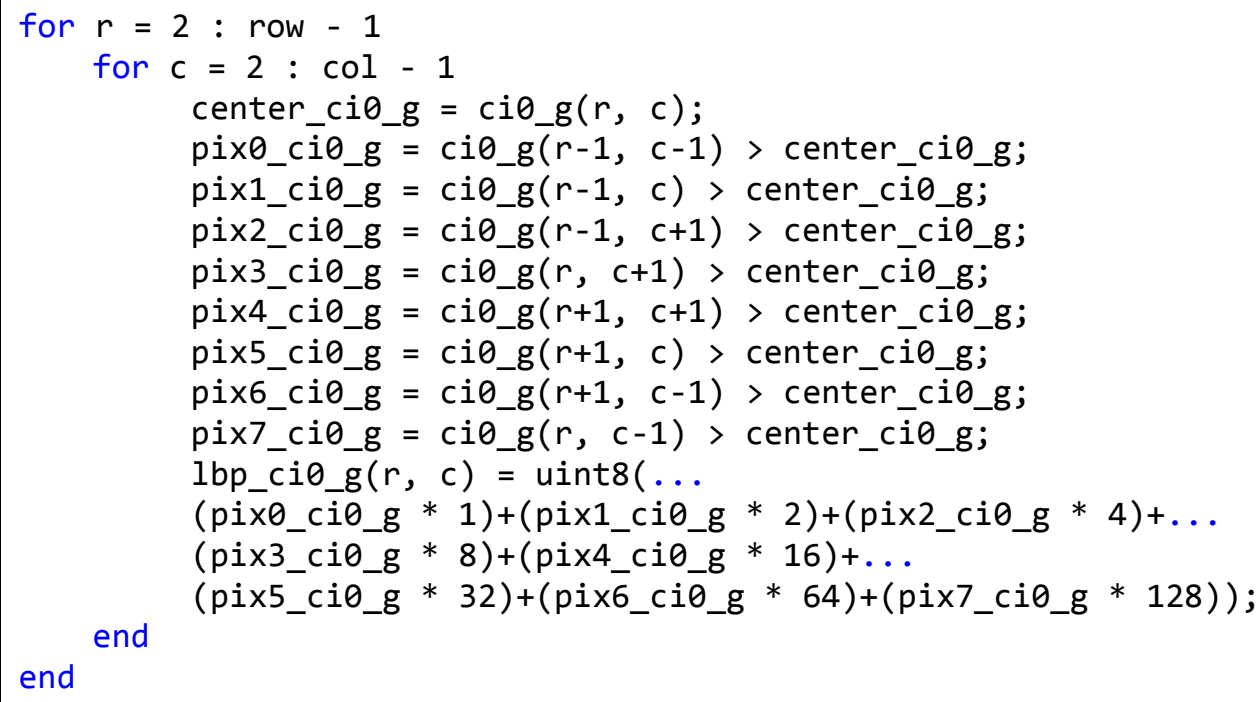

Berikut ini algoritma yang digunakan pada proses ekstraksi ciri (fitur) dari matrik citra LBP untuk mean, standar deviasi, entropy, skewness, dan kurtosis.

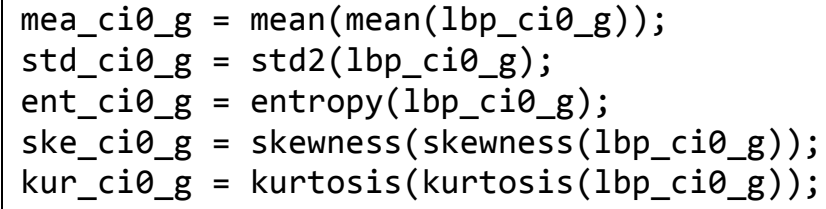

\section{Pelatihan JST}

Metode pengenalan yang digunakan adalah Jaringan Syaraf Tiruan Propagasi Balik (JST-BP). Tahap ini diperlukan karena JST BP membutuhkan pelatihan untuk mengubah bobot nilai yang ada dalam jaringan agar masukan (input) sesuai dengan target (output). Jika semua pasangan masukan dan keluaran sudah sesuai, maka JST sudah bisa digunakan untuk pengujian. Gambar 6 merupakan arsitektur JST lapis tunggal, dan Gambar 7 merupakan arsitektur JST lapis banyak. Penelitian ini menggunakan arsitektur JST lapis banyak. 


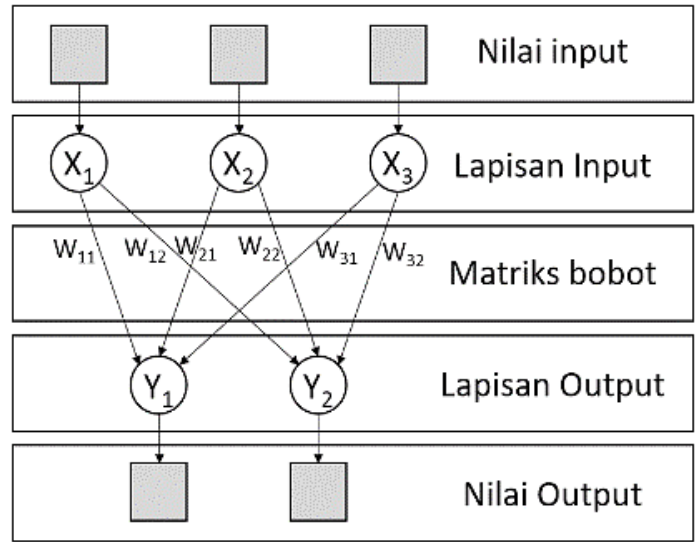

Gambar 6. Model Arsitektur JST Lapis Tunggal [8]

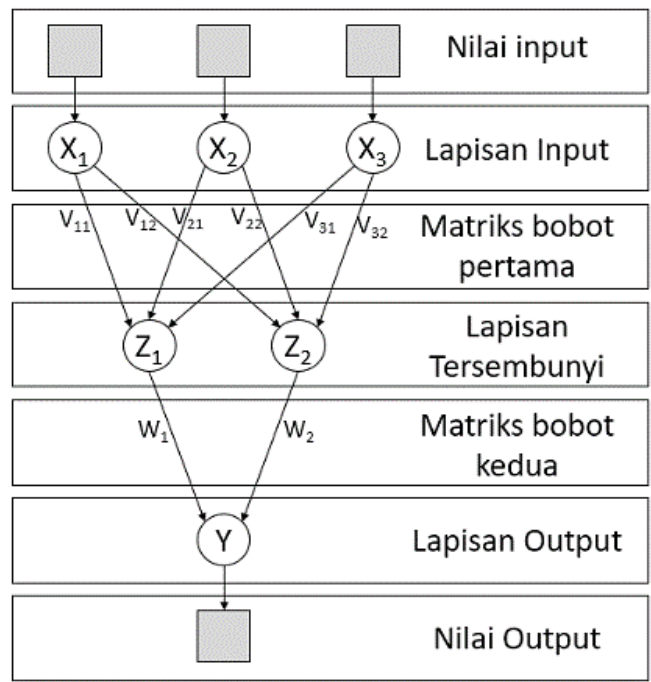

Gambar 7. Model Arsitektur JST Lapis Jamak [8]

Proses pelatihan membutuhkan target output tiap untuk tiap sampel dari tiap jenis campuran. Tabel 2 menggambarkan nilai-nilai neuron output dari jaringan syaraf tiruan yang ditampilkan dalam bentuk baris, yaitu Neuron 1 s.d. Neuron 6. Sebagai contoh, jika Neuron 4 memberikan output 1 dan neuron lainnya memberikan output 0 , maka input yang diterima JST adalah jenis 4 (kolom jenis 4).

Tabel 2. Definisi Target

\begin{tabular}{|c|c|c|c|c|c|c|c|}
\hline & \multicolumn{6}{|c|}{ Jenis Campuran Semen Pasir } \\
\hline & & $\begin{array}{c}\text { Jenis 1 } \\
(1-1)\end{array}$ & $\begin{array}{l}\text { Jenis } 2 \\
(1-1,5)\end{array}$ & $\begin{array}{c}\text { Jenis } 3 \\
(1-2)\end{array}$ & $\begin{array}{l}\text { Jenis } 4 \\
(1-2,5)\end{array}$ & $\begin{array}{c}\text { Jenis } 5 \\
(1-3)\end{array}$ & $\begin{array}{l}\text { Jenis } 6 \\
(1-3,5)\end{array}$ \\
\hline \multirow{6}{*}{ 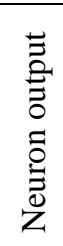 } & Neuron 1 & 1 & 0 & 0 & 0 & 0 & 0 \\
\hline & Neuron 2 & 0 & 1 & 0 & 0 & 0 & 0 \\
\hline & Neuron 3 & 0 & 0 & 1 & 0 & 0 & 0 \\
\hline & Neuron 4 & 0 & 0 & 0 & 1 & 0 & 0 \\
\hline & Neuron 5 & 0 & 0 & 0 & 0 & 1 & 0 \\
\hline & Neuron 6 & 0 & 0 & 0 & 0 & 0 & 1 \\
\hline
\end{tabular}


Proses pembentukan arsitektur JST pada penelitian ini adalah dengan cara melakukan eksperimen terhadap beberapa jumlah neuron pada satu lapisan tersembunyi. Jika arsitektur JST dengan satu lapisan tersembunyi belum mampu mengenali semua datalatih, maka dari beberapa eksperimen satu lapisan tersembunyi diambil tiga arsitektur yang memiliki tingkat akurasi pengenalan yang tinggi. Selanjutnya tiga arsitektur tersebut dilakukan kombinasi untuk lapisan tersembunyi kedua. Kemudian diambil tiga arsitektur yang memiliki tingkat akurasi tertinggi untuk dikombinasikan sebagai lapisan ketiga. Demikian seterusnya hingga JST mampu mengenali semua data latih.

\section{Pengujian}

Pengujian merupakan tahap pengujian atas JST yang sudah melalui tahap pelatihan, yaitu JST yang mampu mengenali data latih terbanyak. Pengujian ini bertujuan untuk melihat tingkat akurasi pengenalan jenis campuran semen pasir jika ekstraksi ciri (fitur) yang digunakan teknik blok citra. Pengujian dilakukan terhadap data yang tidak digunakan pada proses pelatihan. Proses pengujian dilakukan pada citra yang sebelumnya melalui tahap yang sama seperti citra latih, mulai dari pembuatan sampel hingga ekstraksi ciri (fitur).

\section{HASIL DAN PEMBAHASAN}

Identifikasi kadar semen dan pasir pada campuran yang sudah mengeras dengan menggunakan 600 data latih dan 120 data uji dengan teknik blok citra dan tekstur LBP menghasilkan tingkat akurasi pengenalan terbesar $80 \%$ (Tabel 3).

Tabel 3. Hasil Pengujian

\begin{tabular}{|l|c|c|c|}
\hline Jenis campuran & Jumlah data uji & Tidak dikenali & Dikenali \\
\hline $1: 1$ & 20 & 0 & 20 \\
\hline $1: 1.5$ & 20 & 0 & 20 \\
\hline $1: 2$ & 20 & 13 & 7 \\
\hline $1: 2.5$ & 20 & 1 & 19 \\
\hline $1: 3$ & 20 & 10 & 10 \\
\hline $1: 3.5$ & 20 & 0 & 20 \\
\hline Total & $\mathbf{1 2 0}$ & $\mathbf{2 4}$ & $\mathbf{9 6}$ \\
\hline
\end{tabular}

Gambar 8 menunjukan arsitektur JST hasil pelatihan yang memiliki 20 nilai input, 77 neuron pada hidden layer pertama, 77 neuron pada hidden layer kedua, serta 79 neuron pada hidden layer ketiga. Output layer menggunakan 6 neuron yang sesuai dengan definisi target yang sudah ditetapkan pada penelitian ini, yaitu dapat dilihat pada Tabel 2. 


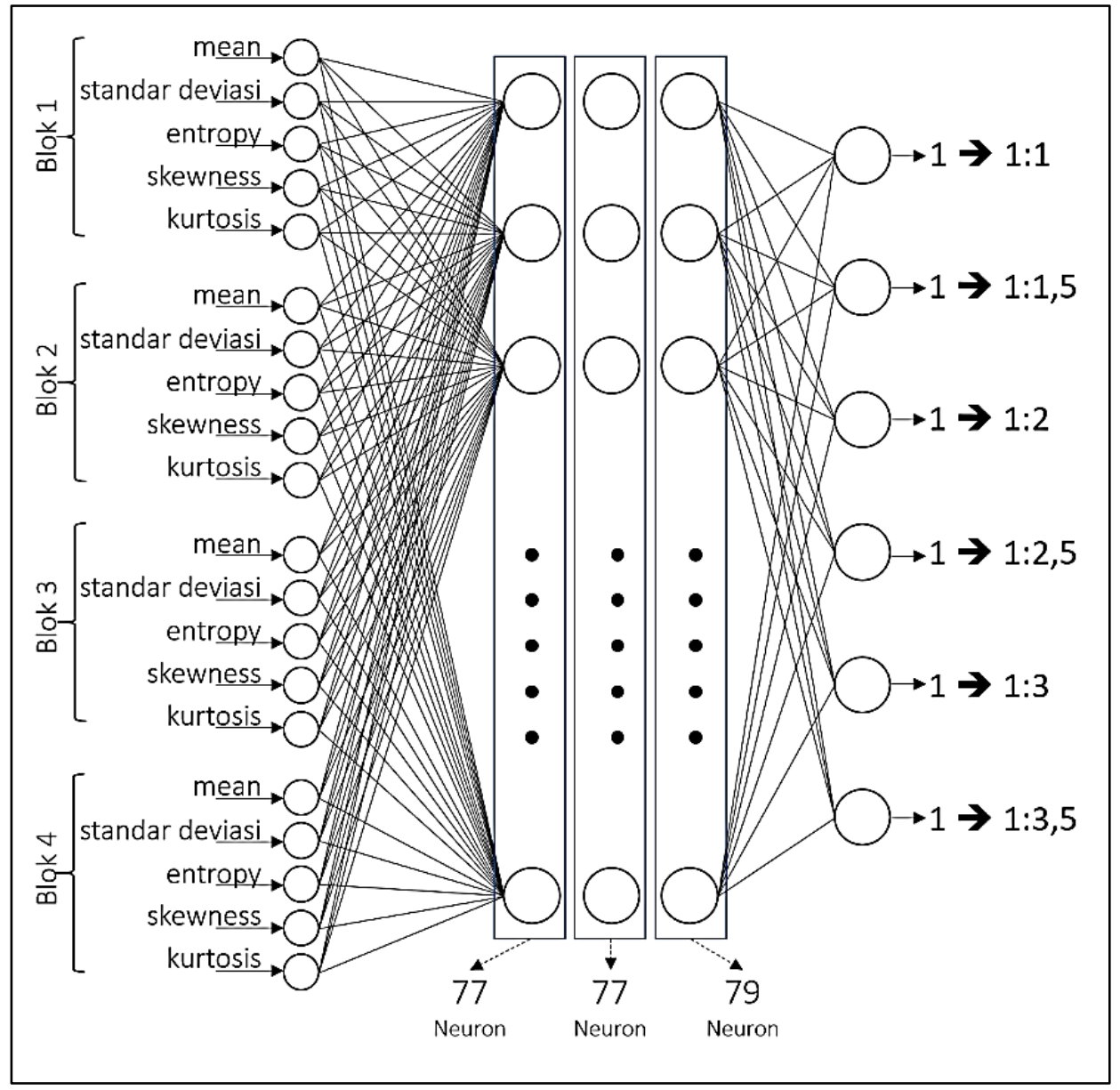

Gambar 8. Model Arsitektur JST

Tabel 4 menyajikan informasi tentang spesifikasi JST yang dihasilkan secara detail dari hasil pelatihan dan pengujian pada penelitian ini.

Tabel 4. Spesifikasi JST

\begin{tabular}{|l|l|}
\hline \multicolumn{1}{|c|}{ Komponen } & Nilai \\
\hline Asitektur & 3 hidden layer \\
\hline Algoritma & Propagasi balik \\
\hline Neuron hidden layer & $77,77,79$ \\
\hline Neuron input layer & $\begin{array}{l}20 \text { neuron : } \\
5 \text { neuron blok 1 (Mean, standar deviasi, } \\
\text { entropy, skewness, dan kurtosis) } \\
5 \text { neuron blok 2 (Mean, standar deviasi, } \\
\text { entropy, skewness, dan kurtosis) } \\
5 \text { neuron blok 3 (Mean, standar deviasi, } \\
\\
\text { entropy, skewness, dan kurtosis) } \\
5 \text { neuron blok 4 (Mean, standar deviasi, } \\
\text { entropy, skewness, dan kurtosis) }\end{array}$ \\
\hline
\end{tabular}




\begin{tabular}{|l|l|}
\hline Neuron output layer & 6 neuron (jenis campuran) \\
\hline MSE & $1 \mathrm{e}-30$ \\
\hline Total data latih & 600 \\
\hline Total data uji & 120 \\
\hline $\begin{array}{l}\text { Akurasi penganalan data } \\
\text { latih }\end{array}$ & $100 \%$ \\
\hline Akurasi penganalan data uji & $80 \%$ \\
\hline
\end{tabular}

\section{KESIMPULAN}

Penelitian ini menggunakan teknik blok citra, yaitu membagi citra menjadi empat bagian sama besar. Teknik ini akan menghasilkan empat citra bagian ditambah satu citra utama, sehingga tardapat lima citra. Terdapat 5 ciri (Mean, standar deviasi, entropy, skewness, dan kurtosis) yang digunakan dalam penelitian ini, sehingga dengan menggunakan teknik blok citra dihasilkan 20 nilai untuk sebuah citra sampel.

Berbeda dengan penelitin sebelumnya [] yang menggunakan ciri (fitur) dari GLCM dan citra tunggal untuk tiap sampel dan mendapatkan tingkat akurasi 87\%. Penelitian ini menggunakan ciri (fitur) statistik yang diambil dari matrik citra LBP, dan mendapatkan tingkat akurasi $80 \%$.

\section{SARAN}

Terdapat beberapa hal yang perlu menjadi perhatian dalam penelitian ini yang diharapkan dapat dilakukan pada penelitian selanjutnya, yaitu:

Perlu adanya perbandingan tingkat akurasi berdasarkan tingkat skala keabuan. Hal ini dikarenakan belum diketahui tingkat skala keabuan yang memberikan akurasi terbaik, baik menggunakan model dari penelitian ini, maupun dari penelitian sebelumnya.

\section{DAFTAR PUSTAKA}

[1] sementigaroda.com. "Mengenal Jenis-jenis Campuran Pasir dalam Adukan Bahan Bangunan Semen". Internet: https://www.sementigaroda.com/read/20150730/170/mengenal-jenis-jenis-campuranpasir-dalam-adukan-bahan-bangunan-semen,2019[16 April 2019]

[2] Gasim \& Sudiadi, 2019, Identifikasi Kadar Semen dan Pasir pada Campuran Kering Menggunakan Metode Backpropagation, Khazanah Informatika: Jurnal Ilmu Komputer dan Informatika, No.1, Vol.5, 37-43, DOI: https://doi.org/10.23917/khif.v5i1.8014

[3] S.M. Mai, A.S. Mariam,S. Amr, 2012,"Automatic Detection of Melanoma Skin Cancer using Texture Analysis,". International Journal of Computer Applications., Vol. 42, No. 20, pp. 22-26.

[4] G. Azim, "Identification of Textile Defects Based on GLCM and Neural Networks, 2015," Journal of Computer and Communications., Vol. 3, No. 12,pp. 1-8. 
[5] H.S.A. Suhair, E.G. Loay, 2017, "Texture Recognition Using Co-Occurrence Matrix Features and Neural Network," Journal of Theoretical and Applied Information Technology., Vol. 95, No.21, pp. 5949-5961.

[6] K.A.Nidhal, S.D. Nizar, A.A. Zaid, 2009, "Skin Texture Recognition Using Neural Networks," Conference: ACIT 2008, Vol. 9.

[7] Gasim, A. Harjoko, K.B. Seminar, S. Hartati, 2013, "Image Blocks Model for Improving Accuracy in Identification Systems of Wood Type," (IJACSA) International Journal of Advanced Computer Science and Applications., Vol. 4, No. 6, pp. 48-53.

[8] Sutojo T, Mulyanto E, dan Vincent, 2010. Kecerdasan Buatan. Andi Offset, Yogyakarta. 